\title{
Bacterioplankton composition in the Scotia Sea, Antarctica, during the austral summer of 2003
}

\author{
Juliette N. Topping ${ }^{1, *}$, Jane L. Heywood ${ }^{1}$, Peter Ward $^{2}$, Mikhail V. Zubkov ${ }^{1}$ \\ ${ }^{1}$ National Oceanography Centre, European Way, Southampton SO14 3ZH, UK \\ ${ }^{2}$ British Antarctic Survey, Natural Environment Research Council, High Cross, Madingley Road, Cambridge CB3 0ET, UK
}

\begin{abstract}
Physical ocean processes (ice-melt, island run-off and upwelling of nutrients) were hypothesised to affect the bacterioplankton composition in the surface mixed layer of the Scotia Sea during the austral summer of 2003, and this was investigated using flow cytometry and catalysed reporter deposition fluorescence in situ hybridisation (CARD-FISH) techniques. The bacterioplankton was composed predominantly of Alphaproteobacteria (PB), comprising SAR11, Roseobacter spp. and SAR116 groups, followed by Sphingobacteria/Flavobacteria and Gammaproteobacteria, including SAR86. Two distinct bacterioplankton communities were identified, largely based on bacterioplankton abundance, which varied from $0.3 \pm 0.06 \times 10^{6} \mathrm{cells} \mathrm{ml}^{-1}$ in the west to $0.8 \pm 0.3 \times 10^{6}$ cells $\mathrm{ml}^{-1}$ in the east, and a corresponding difference in SAR11 percentages of $30 \pm 15 \%$ in the west compared to $5 \pm 5 \%$ in the east. The western community was present in waters that were largely in an over-wintered, pre-bloom condition. The eastern bacterioplankton community was associated with phytoplankton blooms developed within the eastern Scotia Sea nutrient upwelling zone, where the Antarctic Circumpolar Current (ACC) encounters the shallow bathymetry associated with the Scotia Arc, in combination with seasonal ice-melt and island effects that enabled surface water stratification.
\end{abstract}

KEY WORDS: Bacterioplankton $\cdot$ Community $\cdot$ CARD-FISH $\cdot$ Flow Cytometry $\cdot$ Scotia Sea $\cdot$ Antarctic Circumpolar Current

Resale or republication not permitted without written consent of the publisher

\section{INTRODUCTION}

Bacterioplankton play key roles in biogeochemical cycling within oceanic environments, and bacterial production is the main outcome of DOM sequestration within the microbial loop, a process known to largely influence the rest of the marine ecosystem (Ducklow 2000). However, these organisms have been understudied within the Southern Ocean. Bacterioplankton abundance in Antarctic waters has previously been found to be higher when associated with ice formation and melt events (Delille 1992, Grossmann 1994, Grossmann \& Dieckmann 1994, Giesenhagen et al. 1999, Delille et al. 2002). Island effects also appear to be significant; for example, bacterioplankton biomass is always higher closer to the Kerguelen Islands archipelago $\left(49.5^{\circ} \mathrm{S} 69.25^{\circ} \mathrm{E}\right)$ than at a station over $100 \mathrm{~km}$ away (Delille 2003). A strong positive relationship has also been found between bacterial abundance and chlorophyll $a$ within the ACC near to the Antarctic Polar Front (APF) (Lochte et al. 1997).

Various patterns of bacterioplankton distribution have previously been found in Antarctic waters. North-south gradients have been observed across fronts; for example at the APF at $170^{\circ} \mathrm{W}$, phytoplankton and bacterioplankton abundances were higher to the north (Brown \& Landry 2001) whereas in the Northern Weddell Sea during austral summer Zdanowski \& Donachie (1993) observed cold winter water in the west (low bacteria/other parameters) but warmer meltwater in the east (high bacteria/other parameters). Several studies have found bacterial abundance in western Antarctic waters during austral summer (or in ice-free stratified water) to be between 2 and $6 \times 10^{5}$ cells $\mathrm{ml}^{-1}$ (Grossmann 1994, Delille \& 
Rosiers 1996, Pedros-Alio et al. 2002, Church et al. 2003). However, bacterial blooms have also been observed during this time with up to $3 \times 10^{6} \mathrm{cells} \mathrm{ml}^{-1}$ (Ducklow et al. 2001).

The spatial variation in bacterioplankton community structure (proportions of different phylogenetic groups) and composition (absolute abundance of these groups) ultimately indicates changes in their environment, but is not well described in the Southern Ocean. One of the few studies undertaken has shown a pronounced dominance of the Sphingobacteria/ Flavobacteria (of the Bacteroidetes phylum) (Garrity et al. 2001) in the psychrophilic bacterioplankton communities from south of the APF to the marginal ice zone, with Alphaproteobacteria and Gammaproteobacteria present in low abundance, and Betaproteobacteria and Archaea absent (Simon et al. 1999). Another study has shown that the Roseobacter-cladeaffiliated cluster constitutes $\sim 20 \%$ of total bacteria in the Weddell Sea (Selje et al. 2004).

With this background a large-scale cruise undertaken in the Scotia Sea in the Atlantic sector of the Southern Ocean during January and February 2003 provided a further opportunity to study Antarctic bacterioplankton. Ice-melt-induced stratification of the water column, island run-off and upwelling of nutrients within the ACC influenced the distribution of chlorophyll biomass and mesozooplankton during this cruise (Korb et al. 2005, Ward et al. 2006). It was of particular interest to see to what extent these physical processes also influenced bacterioplankton abundance, distribution and composition.

\section{MATERIALS AND METHODS}

Samples were collected during a British Antarctic Survey cruise (JR82) on board RRS 'James Clark Ross' (for full details and results of plankton studies, see Ward et al. 2006). Eight zig-zag transects across the Scotia Sea were run in January/February 2003, starting north of the Elephant Island and traversing eastwards (see Fig. 1). The transects crossed the ACC running southwest to northeast through the study area. At each station (see Fig. 1), water samples were collected at 9 vertical depths (20 to $200 \mathrm{~m}$ ) using a rosette of water bottles mounted on a CTD profiler. At each station/depth, $2 \mathrm{ml}$ seawater subsamples were placed in glass vials and fixed with formaldehyde (1\% final concentration) and maintained at $+2{ }^{\circ} \mathrm{C}$ for $24 \mathrm{~h}$. The vials were then stored frozen at $-80^{\circ} \mathrm{C}$ until analysed ashore: bacterioplankton was enumerated using flow cytometry and its composition was determined using catalysed reporter deposition fluorescence in situ hybridisation (CARD-FISH) techniques.
Flow cytometry. Total bacterioplankton were enumerated with a FACSort flow cytometer (Becton Dickinson) in samples stained with SYBR Green I DNA dye (Marie et al. 1997). Yellow-green $0.5 \mu \mathrm{m}$ bead standards (Fluoresbrite Microparticles, Polysciences) of calibrated concentration were used in all analyses to determine absolute cell concentrations (Zubkov et al. 2002).

CARD-FISH. Station samples used for CARD-FISH were chosen so as to be representative of the study area (see Fig. 1). Samples from $40 \mathrm{~m}$ were used to provide information on bacterioplankton composition in surface waters. The CARD-FISH technique employed was based on that of Pernthaler et al. (2002) and Fuchs et al. (2005). Water samples were spotted in $100 \mu \mathrm{l}$ volumes per segment of a polycarbonate filter with pore size $0.2 \mu \mathrm{m}$ prior to embedding in $0.2 \%$ agarose. Following cell permeabilisation for $1 \mathrm{~h}$ at $37^{\circ} \mathrm{C}$ with lysozyme solution $\left(10 \mathrm{mg} \mathrm{ml}^{-1}\right.$ in $0.05 \mathrm{M}$ EDTA, $0.1 \mathrm{M}$ Tris- $\mathrm{HCl}, \mathrm{pH}$ 8.0), a further incubation with achromopeptidase solution $\left(60 \mathrm{U} \mathrm{ml}^{-1}\right.$ in $0.01 \mathrm{M} \mathrm{NaCl}$, $0.01 \mathrm{M}$ Tris- $\mathrm{HCl}, \mathrm{pH} 8.0$ ) at $37^{\circ} \mathrm{C}$ for $30 \mathrm{~min}$ was performed. Hybridisation was carried out with segments mounted on slides and 100 $\mu$ l of a 300:1 hybridisation buffer:probe (25 $\mathrm{ng} \mathrm{\mu l}^{-1}$ ) mix added to each segment with the appropriate formamide concentration for the probe. The probe sequences, hybridisation conditions, and references are given in Table 1 . The slides were placed in hybridisation chambers in an oven at $46^{\circ} \mathrm{C}$ for $2 \mathrm{~h}$. Filter segments were then washed in a prewarmed $\left(48^{\circ} \mathrm{C}\right)$ washing buffer for $15 \mathrm{~min}$. After probe equilibration and catalysed reporter deposition (see Fuchs et al. 2005), segments were counterstained with 4',6-diamidino-2-phenylindole (DAPI). The DAPI-stained and probe-hybridised cells were manually counted under an epifluorescence microscope (Zeiss Axiovert 200M) equipped with a 100× objective. A minimum of 300 DAPI stained cells were counted per segment. Multi-field counts for a sample hybridised with a probe indicated the amount of variation within a segment. For example, the standard deviation of the percentage of the probe-positive cells of the Eub group present in 17 different fields was $7 \%$.

Data analysis. The CellQuest software (Becton Dickinson Biosciences) was used for operating the flow cytometer and data analyses. For statistical analysis of CARD-FISH data, cluster analysis was used, which provided a dendrogram to indicate any station groupings (Clarke \& Warwick 1994). Cluster analysis was based on Bray-Curtis similarities on untransformed data and was conducted using the PRIMER 5 software (Clarke \& Gorley 2001). For comparison of average data between the 2 regions identified, $t$-tests were performed to show any significant differences (SigmaPlot software version 9.0). 
Table 1. Probes used during CARD-FISH; sequence, target phylogenetic group, formamide concentration (FMC) used for hybridisation buffer (at $46^{\circ} \mathrm{C}$ ), and data source. S/F bacteria = Sphingobacteria/Flavobacteria

\begin{tabular}{|lllcc|}
\hline Probe & \multicolumn{1}{c}{ Sequence 5'-3' } & Target group & FMC (\%) & Source \\
\hline Eub338 & GCTGCCTCCCGTAGGAGT & Bacteria & 35 & Amann et al. (1990) \\
Eury806 & CACAGCGTTTACACCTAG & Archaea & Teira et al. (2004) \\
Cren554 & TTAGGCCCAATATCMTCCT & Archaea & Massana et al. (1997) \\
Alf968 & GGTAAGGTTCTGCGCGTT & Alphaproteobacteria & 35 & Neef (1997) \\
SAR11/486 & GGACCTTCTTATTCGGGT & SAR 11 & 40 & Fuchs et al. (2005) \\
SAR11/542R & TCCGAACTACGCTAGGTC & SAR 11 & 40 & Morris et al. (2002) \\
Ros537 & CAACGCTAACCCCCTCC & Roseobacter & 35 & Eilers et al. (2001) \\
SAR116 1-447 & GCTACCGTCATCATCTTC & SAR116 & 25 & Fuchs et al. (2005) \\
SAR116 2-436 & CATCTTCACCAGTGAAAG & SAR116 & 25 & Fuchs et al. (2005) \\
Gam42a & GCCTTCCCACATCGTTT & Gammaproteobacteria & 35 & Manz et al. (1992) \\
SAR86/1245 & TTAGCGTCCGTCTGTAT & SAR86 & 35 & Zubkov et al. (2001) \\
CF319a & TGGTCCGTGTCTAGTAC & S/F bacteria & 35 & Manz et al. (1996) \\
\hline
\end{tabular}

\section{RESULTS AND DISCUSSION}

The bacterioplankton in the Scotia Sea were dominated by Alphaproteobacteria, Gammaproteobacteria and Sphingobacteria/Flavobacteria, with Archaea in low percentages (Table 2). Members of the SAR11 clade dominated Alphaproteobacteria, with Roseobacter spp. and members of the SAR116 clade also present (Table 2). The Roseobacter clade (Ros537) constituted less of the total bacteria than previously observed in the nearby Weddell Sea (Selje et al. 2004). Gammaproteobacteria included SAR86 clade (Table 2), but most of this group remained unidentified by the probes used. Structurally, the bacterioplankton in the Scotia Sea differed from those found to the east in the Atlantic sector of the Southern Ocean by Simon et al. (1999), where Sphingobacteria/Flavobacteria alone dominated and Gammaproteobacteria Archaea were rare/ absent, showing that bacterioplankton is a dynamic community of the ACC surface waters and, perhaps, indicating the organic matter decomposition of the advected eastern Scotia Sea phytoplankton bloom by Sphingobacteria/Flavobacteria. In the west of the Scotia Sea, there were high proportions of Alphaproteobacteria and SAR11; on average, $96 \%$ of Bacteria were identified by generic probes. For comparison, in the east of the Scotia Sea, Alphaproteobacteria were equally dominant with Gammaproteobacteria and Sphingobacteria/Flavobacteria, together identifying just $64 \%$ of Bacteria.

Western (WR) and eastern (ER) regions were clearly identified within the Scotia Sea, based on the structure and composition of the bacterioplankton (Figs. $1 \& 2$, Tables 2 \& 3). WR contained higher proportions of Alphaproteobacteria and SAR11 than ER (Table 2). Conversely ER had higher abundances of total bacteri-
Table 2. Structure (\% probe-positive cells) and abundance $\left(\times 10^{3}\right.$ cells ml $\left.{ }^{-1}\right)$ of bacterioplankton in 2 regions identified in the Scotia Sea. Data are averages across stations within the 2 regions $\pm \mathrm{SD}$. Physical and chemical data averaged over both flow cytometry and FISH stations are given (nutrients in mmol $\mathrm{m}^{-3}$; chl a data integrated over 0 to $100 \mathrm{~m}$ ). Results of $t$-test shown; significant differences $(\mathrm{p}<0.05)$ are in bold, $\mathrm{df}=11$ $\left({ }^{*}\right), 31\left({ }^{* *}\right)$ or $25\left({ }^{* * *}\right)$. Note: FISH and flow cytometry conducted at different stations within the regions. Chlorophyll a data is from oceanic stations only, since South Georgia stations have exceptionally high levels $\left(295 \pm 122 \mathrm{mg} \mathrm{m}^{-2}\right)$. S/F bacteria: Sphingobacteria/Flavobacteria

\begin{tabular}{|c|c|c|c|}
\hline \multirow[t]{2}{*}{ Probe/group } & \multicolumn{2}{|c|}{ Region } & \multirow[t]{2}{*}{ p-values } \\
\hline & West (WR) & East (ER) & \\
\hline \multicolumn{4}{|c|}{ Bacterioplankton community structure (WR $\mathrm{n}=8, \mathrm{ER} \mathrm{n}=5$ ) } \\
\hline Archaea & $1 \pm 2$ & $3 \pm 2$ & $0.1^{*}$ \\
\hline Bacteria & $87 \pm 12$ & $89 \pm 3$ & $0.80^{*}$ \\
\hline Alphaproteobacteria & $52 \pm 16$ & $23 \pm 11$ & $0.005^{*}$ \\
\hline SAR11 & $32 \pm 15$ & $5 \pm 5$ & $0.002^{*}$ \\
\hline $\operatorname{Ros} 537$ & $7 \pm 3$ & $6 \pm 3$ & $0.8^{*}$ \\
\hline SAR116 & $4 \pm 3$ & $4 \pm 2$ & $0.65^{*}$ \\
\hline Gammaproteobacteria & $12 \pm 10$ & $17 \pm 5$ & $0.36^{*}$ \\
\hline SAR86 & $2 \pm 2$ & $2 \pm 2$ & $0.93^{*}$ \\
\hline S/F bacteria & $20 \pm 13$ & $17 \pm 7$ & $0.61^{*}$ \\
\hline \multicolumn{4}{|c|}{ Bacterioplankton abundance (WR $n=6, E R n=16$ ) } \\
\hline All bacteria & $332 \pm 62$ & $819 \pm 352$ & $\begin{array}{c}\mathbf{0 . 0 0 6} \\
(\mathrm{df}=20)\end{array}$ \\
\hline Synechococcus & $0.014 \pm 0.005$ & $0.002 \pm 0.002$ & $\begin{array}{c}\mathbf{0 . 0 0 1} \\
(\mathrm{df}=19)\end{array}$ \\
\hline \multicolumn{4}{|l|}{ Physical/chemical data } \\
\hline Salinity (psu) & $34.08 \pm 0.25$ & $33.99 \pm 0.16$ & $0.20^{* *}$ \\
\hline Temp. $\left({ }^{\circ} \mathrm{C}\right)$ & $0.29 \pm 1.42$ & $1.40 \pm 2.02$ & $0.09^{* *}$ \\
\hline $\mathrm{NO}_{3}^{-}+\mathrm{NO}_{2}^{-}$ & $29.7 \pm 3.0$ & $25.3 \pm 6.5$ & $0.025^{* *}$ \\
\hline $\mathrm{PO}_{4}{ }^{3-}$ & $1.94 \pm 0.21$ & $1.64 \pm 0.46$ & $0.03^{* *}$ \\
\hline $\mathrm{NH}_{4}$ & $0.62 \pm 0.51$ & $1.25 \pm 0.82$ & $0.017^{* *}$ \\
\hline Silicate & $62.8 \pm 21.3$ & $37.9 \pm 31.7$ & $0.018^{* *}$ \\
\hline Chl a $\left(\mathrm{mg} \mathrm{m}^{-2}\right)$ & $23 \pm 11$ & $47 \pm 33$ & $0.022^{* * *}$ \\
\hline
\end{tabular}




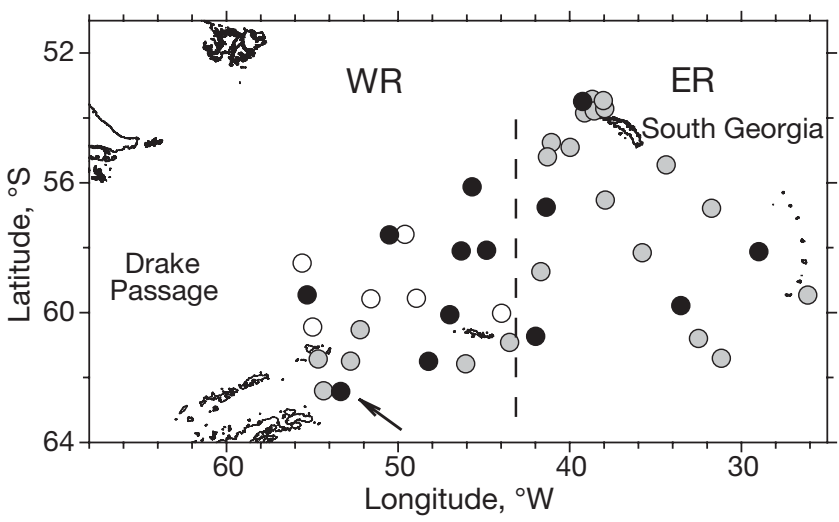

Fig. 1. Station locations (circles) with the western (WR) and eastern (ER) regions identified on the basis of bacterioplankton structure and composition, and divided by a dashed line. (O) Stations at which bacterioplankton concentrations were determined (using flow cytometry) and physical/chemical measurements were made. $(\bullet)$ Stations at which bacterioplankton structure was determined (using CARD-FISH) and physical/chemical measurements were made. (O) Stations at which only physical/chemical measurements were made. An arrow indicates the outlier station (see 'Results and discussion' for details)

oplankton, including Synechococcus spp. of cyanobacteria, although the latter had a very low abundance overall (Table 2). Salinity and temperature did not differ significantly between the 2 regions, but nutrients did differ, with all except ammonia in lower quantities in ER (Table 2). Chlorophyll a concentrations were also higher in ER, especially near South Georgia (Table 2). All these differences were shown to be statistically significant by $t$-tests (Table 2). Cluster analysis on the FISH data also separated these 2 regions, with 1 outlier: a southerly station close to the ice-edge at which bacterioplankton could have been affected by icemelting (Fig. 2 ).

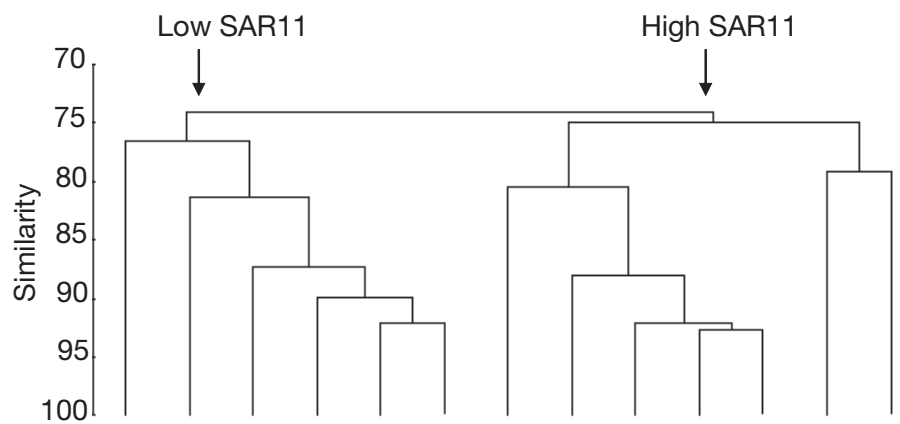

$58^{\circ} \mathrm{S} 62^{\circ} \mathrm{S} 58^{\circ} \mathrm{S} 61^{\circ} \mathrm{S} 60^{\circ} \mathrm{S} 53^{\circ} \mathrm{S} 62^{\circ} \mathrm{S} 58^{\circ} \mathrm{S} 59^{\circ} \mathrm{S} 59^{\circ} \mathrm{S} 58^{\circ} \mathrm{S} 61^{\circ} \mathrm{S} 60^{\circ} \mathrm{S}$ $29^{\circ} \mathrm{W} 53^{\circ} \mathrm{W} 42^{\circ} \mathrm{W} 44^{\circ} \mathrm{W} 34^{\circ} \mathrm{W} 39^{\circ} \mathrm{W} 46^{\circ} \mathrm{W} 46^{\circ} \mathrm{W} 51^{\circ} \mathrm{W} 55^{\circ} \mathrm{W} 50^{\circ} \mathrm{W} 48^{\circ} \mathrm{W} 47^{\circ} \mathrm{W}$

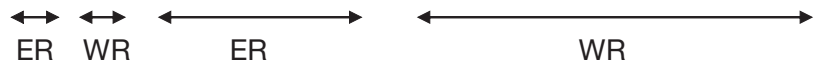

Fig. 2. Cluster analysis dendrogram displaying percentage similarity of stations with corresponding coordinates based on bacterioplankton structure data obtained from CARD-FISH, with western (WR) and eastern (ER) regions indicated
Table 3. Comparison of bacterioplankton community composition in the surface mixed layer of western and eastern regions of the Scotia Sea. Average composition of bacterioplankton $\left(\times 10^{3}\right.$ cells $\left.\mathrm{ml}^{-1}\right)$ was computed using FISH-probe proportions and total bacterioplankton abundance across the 2 regions. Results of $t$-test shown; significant differences $(\mathrm{p}<$ 0.05 ) are in bold, df $=11$. S/F bacteria: Sphingobacteria/ Flavobacteria

\begin{tabular}{|lccl|}
\hline \multirow{2}{*}{ Probe/group } & \multicolumn{2}{c}{ Region } & p-values \\
& West (WR) & East (ER) & \\
\hline Archaea & $4.4 \pm 5.6$ & $25.3 \pm 15.0$ & $\mathbf{0 . 0 0 4}$ \\
Bacteria & $290 \pm 42$ & $729 \pm 26$ & $\mathbf{0 . 0 0 0 1}$ \\
Alphaproteobacteria & $171 \pm 53$ & $191 \pm 88$ & 0.611 \\
SAR11 & $108 \pm 50$ & $38.3 \pm 38.8$ & $\mathbf{0 . 0 2 4}$ \\
Ros537 & $22 \pm 10$ & $51 \pm 21$ & $\mathbf{0 . 0 0 6}$ \\
SAR116 & $13.1 \pm 8.6$ & $31.9 \pm 13.7$ & $\mathbf{0 . 0 1 4}$ \\
Gammaproteobacteria & $40.2 \pm 31.7$ & $136 \pm 42$ & $\mathbf{0 . 0 0 1}$ \\
SAR86 & $7.8 \pm 8.2$ & $18.3 \pm 17.0$ & 0.158 \\
S/F bacteria & $67.0 \pm 41.6$ & $136 \pm 58$ & $\mathbf{0 . 0 2 8}$ \\
\hline
\end{tabular}

The composition of the bacterioplankton (Table 3) shows the actual abundances of bacteria that were present, and can differ as to structure, i.e. group percentages in the community. Indeed, there were similar abundances of Alphaproteobacteria between the 2 regions (Table 3), whereas the proportions differed (Table 2). However, SAR11 was both highly abundant and proportionally dominant in WR (Tables 2 \& 3). Roseobacterspp., SAR116, Gammaproteobacteria, Archaea and Sphingobacteria/Flavobacteria abundances were higher in ER even though they had similar proportions in WR and ER (Tables 2 \& 3). This suggests that as SAR11 abundance was lower in the more productive ER, the other prokaryotic groups, in particular Gammaproteobacteria and Sphingobacteria/Flavobacteria, were able to flourish and reached higher abundances.

The regions identified in this study appear consistent with those described by Korb et al. (2005), who examined primary production across the Scotia Sea in relation to the physico-chemical environment, and Ward et al. (2006), who examined plankton community structure during the same cruise. Enhanced primary production in the eastern Scotia Sea during austral summer of 2003, reported by Korb et al. (2005), was variously attributed to ice-melt in the southeast, island run-off of nutrients (e.g. iron) near the island of South Georgia, and upwelling of nutrients from sediment due to underwater plateaus/ridges encountered by the $\mathrm{ACC}$ as it flowed eastwards into this region. Ice-melt in the southeast was observed to cause stabilization of the water column, resulting in shallow mixed layers that restricted phytoplankton to the euphotic zone, thus maximising growth in this region. This stratification of the water column in ER and consequential phytoplankton growth would result in higher organic matter 


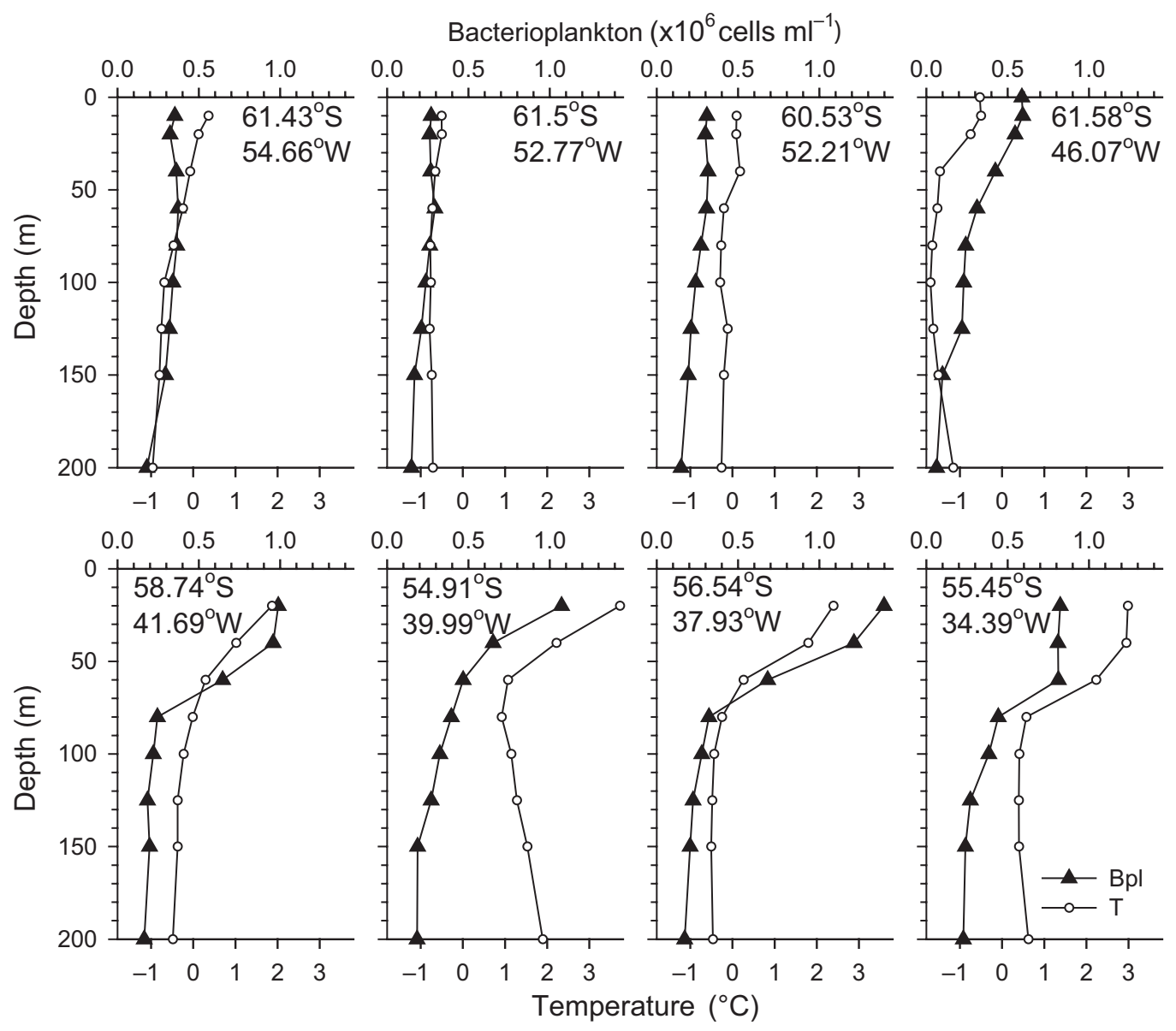

Fig. 3. Depth profiles of bacterioplankton (Bpl) abundance and temperature $(\mathrm{T})$ at stations representing western (top panels) and eastern (bottom panels) regions

input, thus stimulating bacterioplankton growth in this region. Ward et al. (2006) also found the region in the vicinity of the Antarctic Peninsula to be characterised by low phytoplankton cell counts and low mesozooplankton abundances, with populations of the latter largely in an over-wintered state. Further east and north, stations were chlorophyll and zooplankton rich and the summer generation was well advanced. In the southern areas of the ER these relatively advanced communities were associated with production associated with the retreating ice-edge.

Diatom blooms have previously been associated with ice-edges, indicated by decreased silicate (Fonda Umani et al. 2005). In the current study, the ice-edge retreating in the southeast may be one reason for the advanced development of the bacterioplankton, with fresh nutrient input from the melting ice and diatom blooms resulting (indeed, silicate was decreased in the east). Bacterioplankton blooms during ice-melt have been shown previously (Delille 1992, Giesenhagen et al. 1999). In the northern part of the ER around the island of South Georgia, diatom blooms are a consis- tent feature over the shelf and surrounding regions during the austral summer. Whilst lying to the north of the seasonal sea-ice zone, production is thought to be consistent with a plentiful supply of macronutrients and the input of iron brought about by the impact of the ACC with the local bathymetry.

The physical processes of ice-melt in the southeast, island run-off and upwelling of nutrients within the ACC, appear to interact in the Scotia Sea, with ice-melt causing stratification and phytoplankton/bacterioplankton growth in ER, exacerbated by fresh nutrient input in this region due to the combined effect of the ocean physics. Thus local physical ocean processes appear to be important in controlling the abundance and community structure of microbiota in this region.

\section{CONCLUSIONS}

The distinct east-west regional distribution of the bacterioplankton appears to be attributable to the development of stratification with corresponding 
growth of phytoplankton responsible for inorganic nutrient depletion in the ER of the Scotia Sea (Ward et al. 2006) and organic nutrient release with consequential growth of bacterioplankton. SAR11 abundance and dominance was lower, while other prokaryotic groups were more abundant in the east, showing a dynamic response of the community to mixed-layer stratification. This further underlines the important relationship between bacterioplankton ecology and ocean physics.

Acknowledgements. We thank officers and crew of the RRS 'James Clark Ross' for assistance in the field during Cruise JR82. Thanks to M. Whitehouse for providing summary temperature, salinity and nutrient data, and R. Korb for providing the chlorophyll data. This work was funded by the National Oceanography Centre Core Programme. The research of M.V.Z. was supported by the NERC advanced research fellowship (NER/I/S/2000/00898). We are grateful to P. H. Burkill for facilitating this work.

\section{LITERATURE CITED}

Amann RI, Krumholz L, Stahl DA (1990) Fluorescent-oligonucleotide probing of whole cells for determinative, phylogenetic, and environmental studies in microbiology. J Bacteriol 172:762-770

Brown SL, Landry MR (2001) Mesoscale variability in biological community structure and biomass in the Antarctic Polar Front region at 170 degrees W during austral spring 1997. J Geophys Res C 106:13917-13930

Church MJ, DeLong EF, Ducklow HW, Karner MB, Preston CM, Karl DM (2003) Abundance and distribution of planktonic Archaea and Bacteria in the waters west of the Antarctic Peninsula. Limnol Oceanogr 48:1893-1902

Clarke KR, Gorley RN (2001) Primer v5: user manual/tutorial. PRIMER-E, Plymouth

Clarke KR, Warwick RM (1994) Change in marine communities: an approach to statistical analysis and interpretation. Natural Environment Research Council, Swindon

Delille D (1992) Marine bacterioplankton at the Weddell Sea ice edge, distribution of psychrophilic and psychrotrophic populations. Polar Biol 12:205-210

Delille D (2003) Seasonal and inter-annual variability of bacterioplankton biomass at station Kerfix, off Kerguelen Islands, Antarctica. Oceanol Acta 26:225-229

Delille D, Rosiers C (1996) Seasonal changes of Antarctic marine bacterioplankton and sea ice bacterial assemblages. Polar Biology 16:27-34

Delille D, Fiala M, Kuparinen J, Kuosa H, Plessis C (2002) Seasonal changes in microbial biomass in the first-year ice of the Terre Adelie area (Antarctica). Aquat Microb Ecol 28:257-265

Ducklow H (2000) Bacterial production and biomass in the oceans. In: Kirchman $O$ (ed) Microbial ecology of the oceans. Wiley, New York

Ducklow H, Carlson C, Church M, Kirchman D, Smith D, Steward G (2001) The seasonal development of the bacterioplankton bloom in the Ross Sea, Antarctica 1994-1997. Deep-Sea Res II 48:4199-4221

Eilers H, Pernthaler J, Peplies J, Glockner FO, Gerdts G, Amann R (2001) Isolation of novel pelagic bacteria from the German Bight and their seasonal contributions to surface picoplankton. Appl Environ Microbiol 67:5134-5142
Fonda Umani S, Monti M, Bergamasco A, Cabrini M, De Vittor C, Burba N, Del Negro P (2005) Plankton community structure and dynamics versus physical structure from Terra Nova Bay to Ross Ice Shelf (Antarctica). J Mar Syst 55:31-46

Fuchs BM, Woebken D, Zubkov MV, Burkill PH, Amann R (2005) Molecular identification of picoplankton populations in contrasting waters of the Arabian Sea. Aquat Microb Ecol 39:145-157

Garrity G, Winters M, Searles D (2001) Taxonomic outline of the prokaryotic genera. In: Garrity G (ed) Bergey's manual of systematic bacteriology. Springer, New York, p 1-39

Giesenhagen HC, Detmer AE, de Wall J, Weber A, Gradinger RR, Jochem FJ (1999) How are Antarctic planktonic microbial food webs and algal blooms affected by melting of sea ice? Microcosm simulations. Aquat Microb Ecol 20: 183-201

Grossmann S (1994) Bacterial-activity in sea-ice and open water of the Weddell Sea, Antarctica - a microautoradiographic study. Microb Ecol 28:1-18

Grossmann S, Dieckmann GS (1994) Bacterial standing stock, activity, and carbon production during formation and growth of sea-ice in the Weddell Sea, Antarctica. Appl Environ Microbiol 60:2746-2753

Korb RE, Whitehouse MJ, Thorpe SE, Gordon M (2005) Primary production across the Scotia Sea in relation to the physico-chemical environment. J Mar Syst 57:231-249

Lochte K, Bjornsen PK, Giesenhagen H, Weber A (1997) Bacterial standing stock and production and their relation to phytoplankton in the Southern Ocean. Deep-Sea Res II 44:321-340

Manz W, Amann R, Ludwig W, Wagner M, Schleifer KH (1992) Phylogenetic oligodeoxynucleotide probes for the major subclasses of proteobacteria: problems and solutions. Syst Appl Microbiol 15:593-600

Manz W, Amann R, Ludwig W, Vancanneyt M, Schleifer KH (1996) Application of a suite of 16S rRNA-specific oligonucleotide probes designed to investigate bacteria of the phylum Cytophaga-Flavobacter-Bacteroides in the natural environment. Microbiology 142:1097-1106

Marie D, Partensky F, Jacquet S, Vaulot D (1997) Enumeration and cell cycle analysis of natural populations of marine picoplankton by flow cytometry using the nucleic acid stain SYBR Green I. Appl Environ Microbiol 63: 186-193

Massana R, Murray AE, Preston CM, DeLong EF (1997) Vertical distribution and phylogenetic characterization of marine planktonic Archaea in the Santa Barbara Channel. Appl Environ Microbiol 63:50-56

Morris RM, Rappe MS, Connon SA, Vergin KL, Siebold WA, Carlson CA, Giovannoni SJ (2002) SAR11 clade dominates ocean surface bacterioplankton communities. Nature 420: $806-810$

Neef A (1997) Application of in situ identification of bacteria to population analysis in complex microbial communities. Technical University, Munich

Pedros-Alio C, Vaque D, Guixa-Boixereu N, Gasol JM (2002) Prokaryotic plankton biomass and heterotrophic production in western Antarctic waters during the 1995-1996 Austral summer. Deep-Sea Res II 49:805-825

Pernthaler A, Pernthaler J, Amann R (2002) Fluorescence in situ hybridization and catalyzed reporter deposition for the identification of marine bacteria. Appl Environ Microbiol 68:3094-3101

Selje N, Simon M, Brinkhoff T (2004) A newly discovered Roseobacter cluster in temperate and polar oceans. Nature 427:445-448 
Simon M, Glockner FO, Amann R (1999) Different community structure and temperature optima of heterotrophic picoplankton in various regions of the Southern Ocean. Aquat Microb Ecol 18:275-284

Teira E, Reinthaler T, Pernthaler A, Pernthaler J, Herndl GJ (2004) Combining catalyzed reporter deposition-fluorescence in situ hybridization and microautoradiography to detect substrate utilization by Bacteria and Archaea in the deep ocean. Appl Environ Microbiol 70:4411-4414

Ward P, Shreeve R, Atkinson A, Korb B, Whitehouse M, Thorpe S, Pond D, Cunningham N (2006) Plankton community structure and variability in the Scotia Sea: austral summer 2003. Mar Ecol Prog Ser 309:75-91

Editorial responsibility: Josep Gasol,

Barcelona, Spain
Zdanowski MK, Donachie SP (1993) Bacteria in the sea-ice zone between Elephant-Island and the SouthOrkneys during the polish sea-ice zone expedition, (December 1988 to January 1989). Polar Biol 13: 245-254

Zubkov MV, Fuchs BM, Burkill PH, Amann R (2001) Comparison of cellular and biomass specific activities of dominant bacterioplankton groups in stratified waters of the Celtic Sea. Appl Environ Microbiol 67:5210-5218

Zubkov MV, Fuchs BM, Tarran GA, Burkill PH, Amann R (2002) Mesoscale distribution of dominant bacterioplankton groups in the northern North Sea in early summer. Aquat Microb Ecol 29:135-144

Submitted: May 24, 2006; Accepted: August 29, 2006 Proofs received from author(s): November 15, 2006 